\title{
Review of Topical Therapies for Beard Enhancement
}

\author{
A. ALMURAYSHID* \\ Department of Medicine, College of Medicine, Prince Sattam Bin Abdulaziz University, Alkharj City 11942, Saudi Arabia
}

\begin{abstract}
Almurayshid: Topical therapies for Beard enhancement
Beards and facial hair are part of male characters and fascination. Topical therapy for beard enhancement may be desired by some men to improve beard growth and density. A review of all reports on topical treatments for beard enhancement is presented here. Searching the United States National Library of Medicine PubMed, exploring all titles containing beard, facial hair or mustache as of July 22, 2020. A total of 445 articles resulted from the initial search. After reviewing the publications three studies match the aim of the review, two of which were double-blind clinical trials, and one was a case report. Topical $3 \%$ minoxidil, as studied by Ingprasert et al., showed a significant increase in hair count, photographic scoring and patient self-assessment. Saeedi et al. studied the use of $2.5 \%$ testosterone gel for men with thalassemia major and found an increase in terminal hair. Vestita et al. published a case report demonstrating unexpected improvement of beard density for a patient using tretinoin $0.05 \%$ cream. Limited evidence on topical treatments for beard enhancement. Topical minoxidil is an off-label treatment to enhance the beard. Other topical options such as testosterone, tretinoin, of bimatoprost could constitute potential treatment options. Further studies needed to recommend the best topical options for men who desire to enhance their beards.
\end{abstract}

Key words: Beard, facial hair, Minoxidil, Testosterone, Tretinoin, Camouflage, Hair Transplant, Laser

The beard and facial hair have been a social expression for men of different cultures. There are various styles from full beard, goatee or sheave and even others ${ }^{[1]}$. Facial hair can affect the social interactions between individuals and alternative sex. The beards offer a more masculine, dominant, and older looking character, as shown by several studies ${ }^{[2,3]}$. Some cultures value the beard from a religious point of view. However, others are more of a racial or community figure ${ }^{[4]}$.

Some women prefer men with beards. Also, preferred by some women if chosen as parenting or long standing partners ${ }^{[2,3]}$. Nevertheless, cultural differences can affect how men express their facial hair and even women's preference for facial hair ${ }^{[1]}$. The beard enhancement would probably be a demand for some men. This article aims to review the available topical therapy for individuals who want to enhance their facial hair. Furthermore, adjuvant and alternative treatments are discussed.

Using the United States National Library of Medicine, PubMed search to find any topical therapy to enhance the beard's growth or density. Explore all titles that contain beard, facial hair or mustache as of July $22^{\text {nd }}$ of 2020 .

*Address for correspondence

E-mail: a.almurayshid@psau.edu.sa

Special Issue 7, 2020
The results were filtered to find any topical treatment used for enhancing the beard. A total of 445 articles resulted from the initial search after reviewing the publications for potential relation to beard enhancement. Three studies matched the review's aim regarding topical therapy for beard enhancement in men. Ingprasert et al. investigated topical $3 \%$ minoxidil for stimulating hair in the beard area. It was a double masked, placebo control, randomized trial.

They demonstrated a significant increase in hair count, photographic scoring and patient self-assessment ${ }^{[5]}$. Saeedi et al. conducted a randomized, double blinded, and controlled studied using $2.5 \%$ testosterone gel treatment for facial hair in men with thalassemia major. They have found an increase in terminal hair in the treatment group ${ }^{[6]}$. Vestita et al. published a case report demonstrating unexpected improvement of beard density for a patient using Tretinoin $0.05 \%$ cream $^{[7]}$. Table 1 summarizes the studies of topical therapies used for beard enhancement.

\section{Topical Therapies}

Facial hair characterize males and underdeveloped facial hair can be stressful for some men ${ }^{[6]}$. Topical minoxidil treatment is commonly used to treat hair loss, such as androgenetic alopecia. Off label use of topical 
minoxidil for facial hair enhancement is reported ${ }^{[8]}$. Minoxidil is known to induce hair growth as a side effect, even in other body sites ${ }^{[9,10]}$.

Ingprasert et al. published a study showing beard enhancement from topical Minoxidil (Table 1) ${ }^{[5]}$. The significant results are promising; however, no other clinical studies were reported. Ingprasert et al. reported the treatment result after $16 \mathrm{w}$ of therapy. The beard's enhancement might be temporary while using topical minoxidil. Longer follow up is needed for long term effects. Other concentrations might be worth investigating for future studies for efficacy and safety.

S. Lee et al. studied Minoxidil $2 \%$ lotion's ability to enhance the eyebrows compared to placebo. They demonstrated significant improvement in the treatment group, including hair count and diameter ${ }^{[11]}$. Another study examined topical Minoxidil 3\% and topical bimatoprost $0.03 \%$ to enhance the eyebrows. The results showed that both treatments were effective with no significant difference; however, contact dermatitis happened more frequently in the minoxidil group. However, the Author concluded that minoxidil is used as the first option for eyebrow enhancement and bimatoprost is the second ${ }^{[12]}$. Both topical treatments might help increase hair density in the beard area.

Minoxidil can induce hair growth through various suggested mechanisms. For example, minoxidil may work by prolonging the anagen phase, showing antiapoptotic markers in the $\operatorname{skin}^{[13]}$. Furthermore, minoxidil can augment dermal papilla's vascular supply by increasing vascular endothelial growth factor $^{[14]}$. It may also act by stimulating adipocyte stem cells to produce growth factors ${ }^{[15]}$. These suggested mechanisms might contribute collectively to the enhancement of hair growth.

M. Saeedi et al. clinical trial showed that topical testosterone increased the beard area's terminal hair in young men who suffer from beta thalassemia major. Hypogonadism and low levels of testosterone are known complications among this population. Therefore, topical testosterone, as suggested by the authors, helps transform the vellus hair into terminal hair $^{[6]}$. The Beard area possesses androgens receptors that influence hair growth ${ }^{[15]}$. In vitro experiment, adding testosterone on beard dermal papilla cells culture caused increased mitotic activities due to androgen dependence ${ }^{[16]}$. Transgender males grow facial hair after receiving testosterone therapy, while anti androgens reduced the beard hair for transgender females ${ }^{[17]}$. These findings are essential to consider when starting topical testosterone.

The topical therapy is Tretinoin, which helped enhance one patient's beard by Vestita et al. This was an incidental finding as the $30 \mathrm{y}$ old man received tretinoin cream for acne treatment ${ }^{[7]}$. Bazzano et al. studied tretinoin therapy for androgenetic alopecia. They reported an increase in terminal hair after using topical Tretinoin in 7 out of 12 individuals ${ }^{[18]}$. Hair growth cycle in animal studies demonstrated that retinoids might increase the anagen phase and decreased the telogen phase ${ }^{[19]}$. However, retinoids such as isotretinoin might induce telogen effluvium ${ }^{[20,21]}$.

TABLE 1: SUMMARY OF STUDIES REVIEWED FOR TOPICAL TREATMENTS USED FOR BEARD ENHANCEMENT

\begin{tabular}{|c|c|c|c|c|c|}
\hline Article & Study type & $\begin{array}{c}\text { Treatment } \\
\text { used }\end{array}$ & Results & $\begin{array}{c}\text { Side } \\
\text { effects }\end{array}$ & Comments \\
\hline $\begin{array}{l}\text { Ingprasert } \\
\text { et al. } \\
201^{6[5]}\end{array}$ & $\begin{array}{l}\text { It is a Randomized } \\
\text { double-masked } \\
\text { placebo-controlled } \\
\text { study for } 16 \mathrm{w} .\end{array}$ & $\begin{array}{l}\text { Minoxidil } 3 \% \\
0.5 \mathrm{ml} \text { applied } \\
\text { twice daily for } \\
16 \mathrm{w} \text {. }\end{array}$ & $\begin{array}{l}\text { The treatment group's significant } \\
\text { results were increased hair } \\
\text { count, self-assessment, and } \\
\text { the global photographic } \\
\text { score; however, there were } \\
\text { no significant hair diameter } \\
\text { changes. }\end{array}$ & $\begin{array}{l}\text { No } \\
\text { significant } \\
\text { side effects } \\
\text { reported }\end{array}$ & $\begin{array}{l}46 \text { males completed the } \\
\text { study out of } 48 .\end{array}$ \\
\hline $\begin{array}{l}\text { M. Saeedi } \\
\text { et al. } \\
2007^{[6]}\end{array}$ & $\begin{array}{l}\text { It is a Randomized, } \\
\text { double-blind } \\
\text { controlled trial for } \\
6 \text { mo. }\end{array}$ & $\begin{array}{l}\text { Testosterone } \\
2.5 \% \text { Gel. } \\
\text { Applied } 2 \mathrm{~cm} \text { of } \\
\text { gel twice daily } \\
\text { for } 6 \text { mo. }\end{array}$ & $\begin{array}{l}\text { It showed a significant increase } \\
\text { in terminal hair in the treatment } \\
\text { group. }\end{array}$ & $\begin{array}{l}\text { Skin } \\
\text { irritation } \\
\text { happened } \\
\text { in one } \\
\text { patient }\end{array}$ & $\begin{array}{c}\text { Total of } 32 \text { males. The } \\
\text { study aims to improve } \\
\text { the facial hair in men } \\
\text { with thalassemia major } \\
\text { who frequently have } \\
\text { hypogonadism. }\end{array}$ \\
\hline $\begin{array}{l}\text { Vestita } \\
\text { et al. } \\
201^{6[7]}\end{array}$ & $\begin{array}{l}\text { Case report of acne } \\
\text { treatment for } 3 \mathrm{mo} \text {. }\end{array}$ & $\begin{array}{l}0.05 \% \text { tretinoin } \\
\text { cream }\end{array}$ & $\begin{array}{c}\text { New increase in density of the } \\
\text { beard }\end{array}$ & $\begin{array}{l}\text { Not } \\
\text { mentioned }\end{array}$ & $\begin{array}{l}\text { Two glycolic acid peel } \\
\text { treatments were given } \\
\text { during treatment. }\end{array}$ \\
\hline
\end{tabular}


Retinoid have a synergetic effect on minoxidil action on hair growth ${ }^{[22,23]}$. This effect may be due to enhanced permeability of the skin, thereby improving drug absorption ${ }^{[24]}$. Tretinoin also stimulates the sulfotransferase enzymes increasing the availability of minoxidil sulfate ${ }^{[25]}$. This metabolite is more potent than the parent drug ${ }^{[26]}$. Testing for sulfotransferase enzyme activity might predict minoxidil responders among androgenetic alopecia patients ${ }^{[27]}$.

Topical treatment options can be combined together or used with other hair enhancement procedures like hair transplant; however, the therapies' safety is essential. These treatments can come with side effects, such as erythema, irritation and contact dermatitis ${ }^{[6,24]}$ Cardiovascular complications may happen after the use of topical minoxidil ${ }^{[28]}$. Topical testosterone can be absorbed systemically and might even induce hirsutism in sexual partners ${ }^{[6]}$.

\section{Camouflage techniques}

Men have used camouflage to cover up the gaps between hair follicles in the face (fig. 1A and 1B). Men are using different pigmented powders, sprays or lotions as concealers for skin between hairs for the scalp. Although used for androgenetic alopecia, it still a useful option for enhancing the beard ${ }^{[29,30]}$. A drawback is that it is a temporary option and removed when exposed to shampoo ${ }^{[29]}$. These quick methods can meet the need of men for special occasions.

\section{Hair Transplant}

Hair transplantation can restore or reshape the beard or mustaches. Follicular unit grafts collected from the scalp donor site similar to treatment of androgenetic alopecia. Hair transplantation can enhance facial hair efficiently

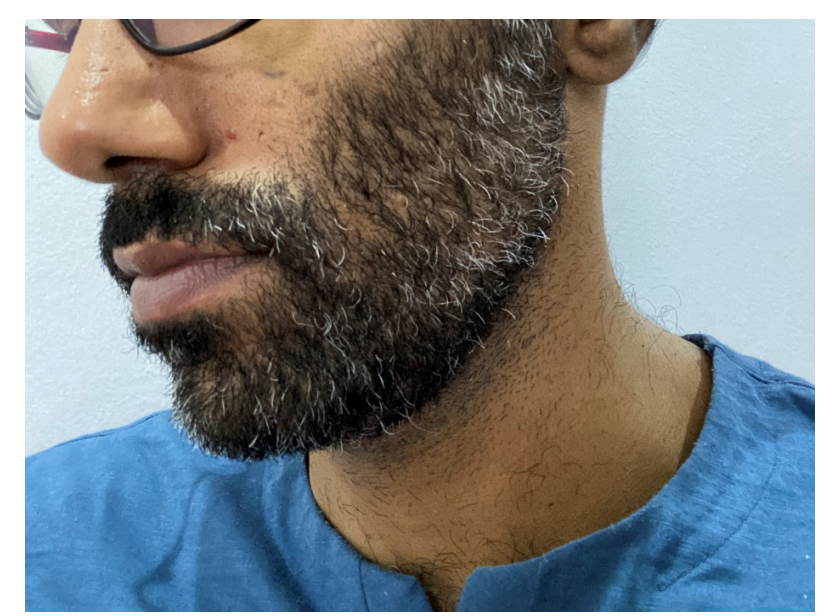

Fig. 1A: This fig is showing the facial hair before using the filling fiber powder.

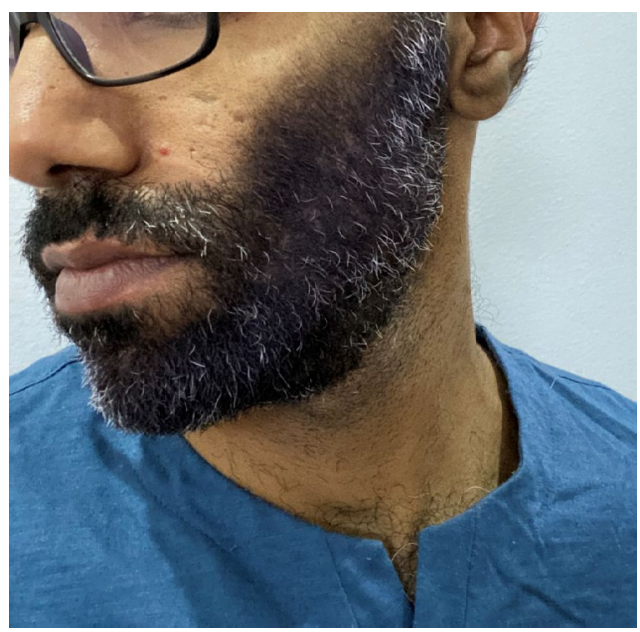

Fig. 1B: Fig is showing the facial hair after using the filling fiber powder. Apparent increase in density of the facial hair.

and satisfy the patient's needs. Patients with a patchy beard can have a full beard if hair grafts are enough ${ }^{[31]}$. However, it is an invasive procedure and requires a skillful hair transplant surgeon. The challenge will be implanting the follicles in the right direction angle of the facial hair ${ }^{[31,32]}$. Furthermore, the patient must be aware of the possibility of repeating the procedure to cover the large areas. Nonetheless, complications like infections, wrong angulation or formation of bumps may occur ${ }^{[32-34]}$. Topical Minoxidil was reported as an adjunctive treatment to hair transplantation of the scalp ${ }^{[35,36]}$. A suggestion could be using minoxidil with facial hair transplantation in future studies, however, existing data supporting minoxidil as a topical medication for beard enhancement ${ }^{[5,8]}$. Platelet rich plasma injection has been used to enhance hair graft survival during hair transplantation ${ }^{[37]}$. Furthermore, Platelet rich plasma injection showed some efficacy in promoting hair growth in androgenetic alopecia ${ }^{[38]}$. Despite Platelet rich plasma's benefit, the existing evidence is limited and further studies are needed for hair transplantation guidelines or hair-enhancing treatments ${ }^{[39,40]}$. Compared to scalp hair, facial hair may differ in response to adjunct therapies like Minoxidil or Platelet rich plasma.

\section{Micropigmentation}

Micropigmentation is using a tattoo to cover the visible skin between the hairs of the scalp ${ }^{[29]}$. Successful Micropigmentation results for androgenetic alopecia treatment reported by Park et al. Their study had 43 receiving this treatment and only one patient was not satisfied ${ }^{[41]}$. Other publications showed Micropigmentation as a possible option for hiding the alopecia or scars ${ }^{[42]}$ However, the tattoo has several 
risks of allergy, infections or pigment change ${ }^{[42,43]}$. Aggravation of skin diseases such as vitiligo can happen from the trauma induced by tattoo placement ${ }^{[44,45]}$. Important aspect is that tattoo procedures are not controlled by health authorities directly. However, stats or governmental regulations are handling it. The latter is also related to non-health artists' practice, affecting the procedure's safety ${ }^{[42]}$. Alopecia areata treated with tattoos for designing the eyebrows with good results; however, the designed eyebrow must be symmetrical and meet patient expectations ${ }^{[46]}$.

\section{Micro Needling}

Kim et al. conducted a study on mice using microneedle application for stimulating hair growth. They have found that micro needling induced hair growth and upregulated the hair growth factors such as vascular endothelial growth factor, Beta Catanin ${ }^{[47]}$. These growth factors play a role in hair growth ${ }^{[47,48]}$. The injury induced by the micro needling initiate the wound healing pathway, favoring hair growth and anagen promotion ${ }^{[49]}$. Clinical studies were done and showed that micro needling could cause hair growth ${ }^{[50]}$. Starace et al. clinical study of micro needling for treating Androgenetic alopecia and telogen effluvium. All patients reported improvement of hair loss after receiving three sessions of micro needling. Side effects include erythema, minimal bleeding and pain, none of which lead to stopping the procedure ${ }^{[50]}$. Micro needling also can have a synergistic impact on topical minoxidil in treating androgenetic alopecia ${ }^{[51,52]}$. This procedure may help the poor responders to Finstride and topical minoxidil ${ }^{[53]}$. The Beard enhancement requires similar studies to know the possible benefits of micro needling. Wound healing of the minimal injuries could be the reason for the hair growth in micro needling ${ }^{[49]}$. One case report of a patient who had new hair in the beard near a wound scar. The authors suggested that the microenvironment of the healing wound may be the reason for the new hair ${ }^{[54,55]}$. Further studies can clarify this theory.

\section{Laser Therapy}

Lasers can help for promoting hair growth in alopecia. Fractional $\mathrm{CO}_{2}$ laser induce hair growth in Alopecia areata as monotherapy ${ }^{[56]}$. The combination of fractional $\mathrm{CO}_{2}$ laser and topical corticosteroids improved the hair growth in resistant cases of Alopecia Areata ${ }^{[57]}$. Salah et al. used fractional $\mathrm{CO}_{2}$ laser as monotherapy and in combination with topical Minoxidil for Androgenetic Alopecia with success ${ }^{[58]}$. Cho, Sung Bin et al. have reported hair growth treating patients using fractional thulium laser $1927 \mathrm{~nm}$. The topical growth factor solution gave better results post laser treatment ${ }^{[59]}$. Ablative or non-ablative fractional lasers may help various alopecia. S. Cho et al. did a retrospective review of 17 patients with different alopecia. In their study, multiple causes include Alopecia Areata, scarring alopecias and autosomal recessive hypotrichosis. However, variable improvement was noticed; long standing Alopecia areata and surgical scar hair loss didn't improve ${ }^{[60]}$.

Low Level Laser Therapy (LLLT) is another treatment for androgenetic alopecia in literature ${ }^{[61-63]}$. Various laser devices available for such treatment modality, including laser comb and laser helmet. Zarei, Mina et al. reviewed LLLT for hair growth in 2015. They found that most studies showed successful hair growth and improvement; however, Several studies did not significantly improve ${ }^{[63]}$. The combination of topical Minoxidil and LLLT has better results for hair growth compared to topical minoxidil alone ${ }^{[64]}$. The lasers may not be easily accessed for patient treatment. The cost effectiveness is significant when recommending such therapy.

Laser treatment for hair enhancement work through several mechanisms. Zhuo et al. studied fractional $\mathrm{CO}_{2}$ laser in a murine model. They found wound healing after laser treatment resulted in hair growth. Growth factors such as Wnt Family Member (WNT) 10b, Vascular endothelial growth factor (VEGF) and Transforming growth factor beta 1 (TGF- $\beta 1$ ) were observed after laser treatment ${ }^{[65]}$. Bae et al. showed in their study similar observations $^{[66]}$. Kim et al. observed an increase in WNT10a after laser treatment using fractional erbium glass in humans. Their pilot study showed a rise in the anagen phase after receiving the laser therapy ${ }^{[67]}$. LLLT therapy uses less energy for hair growth stimulation. Zhang et al. demonstrated that LLLT could stimulate the WNT- $\beta$ catanin pathway. They concluded that LLLT leads to upregulation of WNT10b and Beta catanin, promoting Mice's hair growth ${ }^{[68]}$. LLLT received Food and Drug Administration (FDA) approval for safety and efficacy for treatment of Androgenetic alopecia ${ }^{[63,69]}$.

Willey et al. reviewed 543 patients after laser hair removal of the face and neck areas. They found 57 cases of new hair growth. The authors suggest that a sub therapeutic energy for hair removal may stimulate the hair to grow ${ }^{[70]}$. Future studies will provide evidence for the LLLT and Beard enhancement. 


\section{Conclusion}

Studies on topical treatments for beard enhancement is limited in the literature. Minoxidil is an off label treatment option to enhance the beard. Other topical options such as testosterone, Tretinoin, bimatoprost may be a potential treatment. Camouflage can help in beard enhancement. Laser therapy and micro needling are utilized for Alopecia treatment; however, further studies will clarify facial hair enhancement benefits. Hair transplant can reshape and enhance beard density. Future studies are needed to recommend topical therapies for patients who desire to increase their beard density.

\section{Conflict of interests:}

The Author declared no conflict of interest.

\section{REFERENCES}

1. Oldmeadow JA, Dixson BJ. The association between men's sexist attitudes and facial hair. Arch Sex Behav 2016;45:891-9.

2. Dixson BJ, Sulikowski D, Gouda-Vossos A, Rantala MJ, Brooks RC. The masculinity paradox: facial masculinity and beardedness interact to determine women's ratings of men's facial attractiveness. J Evol Biol 2016;29:2311-20.

3. Dixson BJ, Kennedy-Costantini S, Lee AJ, Nelson NL. Mothers are sensitive to men's beards as a potential cue of paternal investment. Horm Behav 2019;113:55-66.

4. Sijpesteijn PM. Beards, Braids, and Moustachios: Exploring the Social Meaning of Hair in the Mediaeval Muslim World. Al-Masaq 2018;30:4-8.

5. Ingprasert $\mathrm{S}$, Tanglertsampan $\mathrm{C}$, Tangphianphan $\mathrm{N}$, Reanmanee C. Efficacy and safety of Minoxidil $3 \%$ lotion for beard enhancement: A randomized, double-masked, placebocontrolled study. J Dermatol 2016;43:968-9.

6. Saeedi M, Kosaryan M, Fekri K, Adabi M, Mahdavi MR. A randomized, double-blind, controlled trial of testosterone gel treatment versus vehicle control on the facial hair of young men with beta-thalassemia major. J Dermatolog Treat 2007;18:271-4.

7. Vestita M, Giudice G, Bonamonte D, Apruzzi D, Filoni A. Beard hair density increase. A possible role of topical tretinoin application?. Dermatol Ther 2016;30.

8. Suchonwanit P, Thammarucha S, Leerunyakul K. Minoxidil and its use in hair disorders: a review. Drug Des Devel Ther 2019;13:2777-86.

9. Chellini PR, Pirmez R, Raso P, Sodre CT. Generalized hypertrichosis induced by topical minoxidil in an adult woman. Int J Trichology 2015;7:182-3.

10. Rampon G, Henkin C, de Souza PR, Almeida HL Jr. Infantile generalized hypertrichosis caused by topical minoxidil. An Bras Dermatol 2016;91:87-8.

11. Lee S, Tanglertsampan C, Tanchotikul M, Worapunpong N. Minoxidil $2 \%$ lotion for eyebrow enhancement: A randomized, double-blind, placebo-controlled, spilt-face comparative study. J Dermatol 2014;41:149-52.

12. Suwanchatchai W, Tanglertsampan C, Pengsalae N,
Makornwattana M. Efficacy and safety of bimatoprost 0.03 $\%$ versus Minoxidil 3\% in enhancement of eyebrows: a randomized, double-blind, split-face comparative study. J Dermatol 2012;10:865-6.

13. Han JH, Kwon OS, Chung JH, Cho KH, Eun HC, Kim KH. Effect of Minoxidil on proliferation and apoptosis in dermal papilla cells of human hair follicle. J Dermatol Sci 2004;34:918.

14. Lachgar S, Charveron M, Gall Y, Bonafe JL. Minoxidil upregulates the expression of vascular endothelial growth factor in human hair dermal papilla cells. Br J Dermatol 1998;138:407-11.

15. Itami S, Sonoda T, Kurata S, Takayasu S. Mechanism of action of androgen in hair follicles. J Dermatol Sci 1994;7:S98-103.

16. Thornton MJ, Hamada K, Messenger AG, Randall VA. Androgen-dependent beard dermal papilla cells secrete autocrine growth factor(s) in response to testosterone unlike scalp cells. J Invest Dermatol 1998;111:727-32.

17. Giltay EJ, Gooren LJ. Effects of sex steroid deprivation/ administration on hair growth and skin sebum production in transsexual males and females. J Clin Endocrinol Metab 2000;85:2913-21.

18. Bazzano GS, Terezakis N, Galen W. Topical tretinoin for hair growth promotion. J Am Acad Dermatol 1986;15:880-93.

19. Bazzano G, Terezakis N, Attia H, Bazzano A, Dover R, Fenton $\mathrm{D}$, et al. Effect of retinoids on follicular cells. J Invest Dermatol 1993;101:S138-42.

20. Kmiec ML, Pajor A, Broniarczyk-Dyła G. Evaluation of biophysical skin parameters and assessment of hair growth in patients with acne treated with isotretinoin. Adv Dermatol Allergol 2013;30:343-9.

21. İslamoglu ZG, Altınyazar HC. Effects of isotretinoin on the hair cycle. J Cosmet Dermatol 2019;18:647-51.

22. Yoo HG, Chang IY, Pyo HK, Kang YJ, Lee SH, Kwon OS, et $a l$. The additive effects of minoxidil and retinol on human hair growth in vitro. Biol Pharm Bull 2007;30:21-6.

23. Kwon OS, Pyo HK, Oh YJ, Han JH, Lee SR, Chung JH, et al. Promotive effect of minoxidil combined with all-trans retinoic acid (Tretinoin) on human hair growth in vitro. J Korean Med Sci 2007;22:283-9.

24. Ferry JJ, Forbes KK, VanderLugt JT, Szpunar GJ. Influence of Tretinoin on the percutaneous absorption of minoxidil from an aqueous topical solution. Clin Pharmacol Ther 1990;47:43946.

25. Sharma A, Goren A, Dhurat R, Agrawal S, Sinclair R, Trueb RM, et al. Tretinoin enhances minoxidil response in androgenetic alopecia patients by upregulating follicular sulfotransferase enzymes. Dermatol Ther 2019;32:e12915.

26. Buhl AE, Waldon DJ, Baker CA, Johnson GA. Minoxidil sulfate is the active metabolite that stimulates hair follicles. J Invest Dermatol 1990;95:553-7.

27. Goren A, Shapiro J, Roberts J, McCoy J, Desai N, Zarrab Z, et al. Clinical utility and validity of minoxidil response testing in androgenetic alopecia. Dermatol Ther 2015;28:13-6.

28. Olsen EA, Dunlap FE, Funicella T, Koperski JA, Swinehart $\mathrm{JM}$, Tschen $\mathrm{EH}$, et al. A randomized clinical trial of $5 \%$ topical minoxidil versus $2 \%$ topical minoxidil and placebo in the treatment of androgenetic alopecia in men. J Am Acad Dermatol 2002;47:377-85.

29. Saed S, Ibrahim O, Bergfeld WF. Hair camouflage: A comprehensive review. Int J Womens Dermatol 2017;3:S75- 
80.

30. Draelos ZD. Camouflage technique for alopecia areata: What is a patient to do? Dermatol Ther 2011;24:305-10.

31. Civaş E, Aksoy B, Aksoy HM, Çalıkoğlu E. Follicular unit extraction as a valuable method for the restoration of beard: Retrospective case series study. J Cosmet Dermatol. 2020;19:2049-56.

32. Bared A. What's New in Facial Hair Transplantation?: Effective Techniques for Beard and Eyebrow Transplantation. Facial Plast Surg Clin 2019;27:379-84.

33. Bared A. Beard Hair Transplantation. Facial Plast Surg Clin North Am 2020;28:237-41.

34. Epstein J. Facial hair restoration: hair transplantation to eyebrows, beard, sideburns, and eyelashes. Facial Plast Surg Clin 2013;21:457-67.

35. Kassimir JJ. Use of topical Minoxidil as a possible adjunct to hair transplant surgery. A pilot study. J Am Acad Dermatol 1987; 16:685-7.

36. Avram MR, Cole JP, Gandelman M, Haber R, Knudsen R, Leavitt MT, et al. The potential role of minoxidil in the hair transplantation setting. Dermatol Surg 2002;28:894-900.

37. Garg S. Outcome of Intra-operative Injected Platelet-rich Plasma Therapy During Follicular Unit Extraction Hair Transplant: A Prospective Randomised Study in Forty Patients. J Cutan Aesthet Surg 2016;9:157-64.

38. Gentile P, Garcovich S, Bielli A, Scioli MG, Orlandi A, Cervelli V. The Effect of Platelet-Rich Plasma in Hair Regrowth: A Randomized Placebo-Controlled Trial. Stem Cells Transl Med 2015;4:1317-23.

39. Merchán WH, Gómez LA, Chasoy ME, Alfonso-Rodríguez CA, Muñoz AL. Platelet-rich plasma, a powerful tool in dermatology. J Tissue Eng Regen Med 2019;13:892-901.

40. Kumaresan M, Mysore V. Controversies in Hair Transplantation. J Cutan Aesthet Surg 2018;11:173-81.

41. Park JH, Moh JS, Lee SY, You SH. Micropigmentation: camouflaging scalp alopecia and scars in Korean patients. Aesthetic Plast Surg 2014;38:199-204.

42. Rassman WR, Pak JP, Kim J, Estrin NF. Scalp micropigmentation: a concealer for hair and scalp deformities. J Clin Aesthet Dermatol 2015;8:35-42.

43. Simunovic C, Shinohara MM. Complications of decorative tattoos: recognition and management. Am J Clin Dermatol 2014;15:525-36.

44. Yadav A, Yadav P, Yadav J, Chander R. Tattoo for Camouflage: A New Cause of Tattoo Regret. Indian Dermatol Online J 2020;11:250-2.

45. Garg G, Thami GP. Micropigmentation: tattooing for medical purposes. Dermatol Surg 2005;31:928-31.

46. Van der Velden EM, Drost BH, Ijsselmuiden OE, Baruchin AM, Hulsebosch HJ. Dermatography as a new treatment for alopecia areata of the eyebrows. Int J Dermatol 1998;37:61721.

47. Kim YS, Jeong KH, Kim JE, Woo YJ, Kim BJ, Kang H. Repeated Microneedle Stimulation Induces Enhanced Hair Growth in a Murine Model. Ann Dermatol 2016;28:586-92.

48. Choi BY. Targeting Wnt//-Catenin Pathway for Developing Therapies for Hair Loss. Int J Mol Sci 2020;21:4915.

49. Ansell DM, Kloepper JE, Thomason HA, Paus R, Hardman MJ. Exploring the "Hair growth-wound healing connection": anagen phase promotes wound re-epithelialization. J Invest Dermatol 2011;131:518-28.

50. Starace M,Alessandrini A, Brandi N, Piraccini BM. Preliminary results of the use of scalp microneedling in different types of alopecia. J Cosmet Dermatol 2020;19:646-50.

51. Dhurat R, Sukesh M, Avhad G, Dandale A, Pal A, Pund P. A randomized evaluator blinded study of effect of microneedling in androgenetic alopecia: a pilot study. Int $\mathrm{J}$ Trichology 2013;5:6-11

52. Kumar MK, Inamadar AC, Palit A. A Randomized Controlled, Single-Observer Blinded Study to Determine the Efficacy of Topical Minoxidil plus Microneedling versus Topical Minoxidil Alone in the Treatment of Androgenetic Alopecia. J Cutan Aesthet Surg 2018;11:211-6.

53. Dhurat R, Mathapati S. Response to Microneedling Treatment in Men with Androgenetic Alopecia Who Failed to Respond to Conventional Therapy. Indian J Dermatol 2015;60:260-3.

54. Sun ZY, Diao JS, Guo SZ, Yin GQ. A very rare complication: new hair growth around healing wounds. J Int Med Res 2009;37:583-6.

55. Jimenez JJ, Wikramanayake TC, Bergfeld W, Hordinsky M, Hickman JG, Hamblin MR, et al. Efficacy and safety of a lowlevel laser device in the treatment of male and female pattern hair loss: a multicenter, randomized, sham device-controlled, double-blind study. Am J Clin Dermatol 2014;15:115-27.

56. El-Husseiny R, Elframawy S, Abdallah M. Comparative study between fractional carbon dioxide laser vs intralesional steroid injection in treatment of alopecia areata. Dermatol Ther 2020;33:e13742.

57. Majid I, Jeelani S, Imran S. Fractional Carbon Dioxide Laser in Combination with Topical Corticosteroid Application in Resistant Alopecia Areata: A Case Series. J Cutan Aesthet Surg 2018;11:217-21.

58. Salah M, Samy N, Fawzy MM, Farrag AR, Shehata H, Hany A. The Effect of the Fractional Carbon Dioxide Laser on Improving Minoxidil Delivery for the Treatment of Androgenetic Alopecia. J Lasers Med Sci 2020;11:29-36.

59. Cho SB, Goo BL, Zheng Z, Yoo KH, Kang JS, Kim H. Therapeutic efficacy and safety of a 1927-nm fractionated thulium laser on pattern hair loss: an evaluator-blinded, splitscalp study. Lasers Med Sci 2018;33:851-9.

60. Cho S, Choi MJ, Zheng Z, Goo B, Kim DY, Cho SB. Clinical effects of non-ablative and ablative fractional lasers on various hair disorders: a case series of 17 patients. J Cosmet Laser Ther 2013;15:74-9.

61. Barikbin B, Khodamrdi Z, Kholoosi L, Akhgri MR, Haj Abbasi M, Hajabbasi M, et al. Comparison of the effects of $665 \mathrm{~nm}$ low level diode Laser Hat versus and a combination of $665 \mathrm{~nm}$ and $808 \mathrm{~nm}$ low level diode Laser Scanner of hair growth in androgenic alopecia. J Cosmet Laser Ther 2017.

62. Suchonwanit P, Chalermroj N, Khunkhet S. Low-level laser therapy for the treatment of androgenetic alopecia in Thai men and women: a 24-week, randomized, double-blind, sham device-controlled trial. Lasers Med Sci 2019;34:1107-14.

63. Zarei M, Wikramanayake TC, Falto-Aizpurua L, Schachner LA, Jimenez JJ. Low level laser therapy and hair regrowth: an evidence-based review. Lasers Med Sci 2016;31:363-71.

64. Faghihi G, Mozafarpoor S, Asilian A, Mokhtari F, Esfahani AA, Bafandeh B, et al. The effectiveness of adding lowlevel light therapy to Minoxidil $5 \%$ solution in the treatment of patients with androgenetic alopecia. Indian J Dermatol Venereol Leprol 2018;84:547-53. 
65. Zhuo FL, Li LF, Cai LQ, Huang Y. Effects of $\mathrm{CO}_{2}$ fractional laser on hair growth in C57BL/6 mice and potential underlying mechanisms. Chin Med J 2019;132:1257-60.

66. Bae JM, Jung HM, Goo B, Park YM. Hair regrowth through wound healing process after ablative fractional laser treatment in a murine model. Lasers Surg Med 2015;47:433-40.

67. Kim WS, Lee HI, Lee JW, Lim YY, Lee SJ, Kim BJ, et al. Fractional photothermolysis laser treatment of male pattern hair loss. Dermatol Surg 2011;37:41-51.

68. Zhang T, Liu L, Fan J, Tian J, Gan C, Yang Z, et al. Lowlevel laser treatment stimulates hair growth via upregulating Wnt $10 \mathrm{~b}$ and $\beta$-catenin expression in $\mathrm{C} 3 \mathrm{H} / \mathrm{HeJ}$ mice. Lasers Med Sci 2017;32:1189-95.

69. Kim H, Choi JW, Kim JY, Shin JW, Lee SJ, Huh CH. Lowlevel light therapy for androgenetic alopecia: a 24-week, randomized, double-blind, sham device-controlled multicenter trial. Dermatol Surg 2013;39:1177-83.

70. Willey A, Torrontegui J, Azpiazu J, Landa N. Hair stimulation following laser and intense pulsed light photo-epilation: review of 543 cases and ways to manage it. Lasers Surg Med 2007;39:297-301.

This is an open access article distributed under the terms of the Creative Commons Attribution-NonCommercial-ShareAlike 3.0 License, which allows others to remix, tweak, and build upon the work non-commercially, as long as the author is credited and the new creations are licensed under the identical terms

This article was originally published in a special issue, "Biomedical Research in Clinical and Preclinical Pharmaceutics" Indian J Pharm Sci 2020:82(3)Spl issue7;19-25 